first few months after President Carter takes office. The following are some of the principal issues which Carter must decide.

- Energy policy. One area in which Carter has frequently attacked the Ford Administration's record is energy policy in general, and nuclear policy in particular. He has offered some specific plans for reorganising the federal energy bureaucracy, and for curbing nuclear proliferation.

Throughout the campaign, Carter made much of the fact that he was trained as a nuclear engineer, and therefore he claims to understand the problems associated with nuclear power. His attitude toward nuclear energy is decidedly cool, promising to minimise the United States' dependence on that source of power, but specifically stating that he does not support a nuclear moratorium. In particular, he has said that he will channel more energy research and development funds into alternative sources such as solar energy and geothermal heat. He has also promised to launch an aggressive energy conservation programme.

Carter has also offered a proposal to consolidate most of the departments and agencies now responsible for energy programmes into a single department. Included would be the Energy Research and Development Administration (ERDA)-which Carter has attacked as being overwhelmingly pro-nuclearthe Federal Energy Agency and the Energy Resources Council. The proposal is likely to meet stiff opposition in Congress, however, since many Congressional committees which now have jurisdiction over individual agencies would be wary of losing some of their authority. A prolonged battle should be anticipated.

On nuclear proliferation, Carter has repeatedly called for a worldwide moratorium on the sale of reprocessing and uranium enrichment plants, and for stringent controls on the export of other nuclear technologies. He has also proposed that an international conference be held to discuss alternative energy sources.

Perhaps the most important nuclear policy question confronting Carter, however, will be whether to permit spent nuclear fuel from commercial power plants to be reprocessed, and the plutonium extracted from it to be recycled as reactor fuel. Just five days before the election, $\mathrm{Mr}$ Ford annuonced that his Administration would defer a decision on reprocessing and recycling plutonium at least until the matter has been given more study. Many nuclear critics, including Carter, called the announcement "too little and too late", but Carter's own policies for recycling have yet to be specifically stated.

Finally, Carter has promised to scale down the effort to develop a liquid metal fast breeder reactor (LMFBR), now the largest single federal energy programme. He has stated that he will reduce the effort to a relatively minor level and, perhaps, seek international participation in it. If Carter decides to reject plutonium recycling and to scale down the LMFBR programme, those actions would constitute major defeats for the long-term plans of the nuclear industry.

- Biomedical research. Virtually nothing has been said during the campaign about the federal government's

\title{
Six-state nuclear battle: results
}

Although the nuclear industry in the United States is not too happy about the fact that last week's election will put into the White House a man who is decidedly cool toward nuclear power, it can at least take considerable comfort from balloting in six states. Voters in Arizona, Colorado, Montana, Ohio, Oregon and Washington soundly rejected propositions which would have placed crippling restrictions on nuclear plants in those states. A similar proposition was defeated in a seventh state, California, last June.

The propositions were rejected so decisively-by margins ranging from $58-42 \%$ in Oregon to $71-29 \%$ in Colorado-that the results constitute a stunning setback for the antinuclear movement in the United States. Spokesmen for the nuclear industry in fact wasted no time in claiming the outcome as a popular endorsement of nuclear energy. Carl Walske, president of the Atomic Industrial Forum, said last week, for example, that nuclear power "has been taken to the Village Square, as Einstein predicted, and has been approved by the American voter".

The defeats were panticularly striking since opinion polls conducted only a month before the election indicated that the propositions stood a good chance of being approved in most of the states. In Colorado and Oregon, they were even leading by a margin of two to one. Anti-nuclear groups blame their defeat on the lavish funding poured into the campaigns during the closing stages by industry and labour groups anxious to swing voter sympathies against the propositions. Pro-nuclear forces are reckoned to have outspent their opponents by about 8 to 1 , and it is noteworthy that in Montana industry groups put up more than $\$ 80,000$ to defeat an anti-nuclear proposition, even though Montana has no nuclear plants and no plans to build any.

The propositions would have forced new nuclear plants to meet three tough requirements before being put into operation. First, there must be no limit to the damages which could be claimed by victims of a nuclear accident - a at present Federal law limits the total liability per accident to $\$ 560$ million. Second, there must be an acceptable, proven technology for getting rid of nuclear wastes. And third, key power plant safety systems must be found to work satisfactorily. The last two conditions would have to be met to the satisfaction of at least two-thirds of the members of state legislatures. Those requirements are so tough that if they were passed in any state they would have vintually halted nuclear expansion in that state. Consequently, the industry fought them on the grounds that they would increase energy prices, discourage industrial expansion and increase unemployment.

The crushing defeat of the propositions in all seven states could have important national implications. For one thing it is likely to take the steam out of attempts in Congress to curb the growth of nuclear power. In the past few years, several bills aimed at halting nuclear expansion at least until a variety of conditions are met have been introduced. Though they have never enjoyed much Congressional support, if voters had demonstrated their enthusiasm for such measures by passing some of the propositions, anti-nuclear forces in Congress would have been given considerable impetus.

The outcome of the referenda is also likely to discourage similar attempts to limit nuclear power through direct ballot in the future. In fact, some nuclear spokesmen are already claiming that the crushing defeat of the propositions will lead to a sharp decline in anti-nuclear sentiment in the United States.

Although such claims will almost certainly prove to be exaggerated, the outcome of the referenda has clearly provided the nuclear industry with considerable ammunition to combat President-elect Carter's reservations about expanding the use of nuclear power in the United States. 